\title{
HOW INDEPENDENT ARE INDEPENDENT REGULATORY AGENCIES?
}

\author{
ALAN B. MORRISON*
}

Asking ine to comment on how independent are independent regulatory agencies is rather like asking me to comment on the weather in Antarctica: I've never been to either place, but I've seen both of thein froin the outside, and at least have soine impressions about them both. Soine of my observations were gleaned while I was an Assistant U.S. Attorney in the Southern District of New York representing both independent and "dependent" executive branch agencies. I also have litigated against both varieties in the 16 years since I left that office. My present office has also been involved at the administrative level with agencies of both kinds, and, as a member of the Adinimistrative Conference of the United States, I have seen representatives of both groups participating in Conference proceedings. Thus, while not an insider, I do have soine impressions of independent agencies, but they should be seen as no inore than one person's view, and not a full attempt to describe that landscape.

There is no official definition of an independent agency, either in the Administrative Procedure Act, or elsewhere. Thus, the term inay be defined in many ways, but for ine an independent agency is one whose meinbers may not be reinoved by the President except for cause, rather than simply because the President no longer wishes them to serve, much as he could disimiss the Secretary of State or other high officials in his administration. To be sure, there are other characteristics generally associated with independent agencies. Typically, they are multi-meinber bodies, they usually have both ruleinaking and adjudicative functions, and there are often limits on the number of ineinbers of one political party who may serve on them at any one time. None of these is a necessary ingredient, nor are they unique to independent agencies.

The basic question to be asked is, how independent are independent agencies? The answer, it seems to me, is "not very." The key person at the independent agencies is the chairman who can be redesignated on an annual basis by the President. In addition, the agency's budget must go through the Office of Manageinent and Budget (OMB), and, with only a minor wrinkle or two, the independents are subject to the requireinents

* Director, Public Citizen Litigation Group, Washington, D.C. 
of the Paperwork Reduction Act ${ }^{1}$ and OMB's authority over the Act. It is true that independent regulatory agencies are not yet subject to the requirements of Executive Order No. 12,291,2 concerning the issuance of rules, but the fact remains that independent agencies are still heavily affected by the White House, especially on important issues, and especially for those members who are interested in being reappointed. Thus, while the independents are inore independent than the executive agencies, the difference in my view is not substantial.

It might be asked, then, what purposes are served by making the agencies independent? The answer that has most often been given is to insulate certam functions from political interference, principally from the White House. But that kind of purpose could be served by statute, which could make certain kinds of interference, for certain kinds of decisions, impernissible, without altering the basic ability of the President to discharge a meinber of a multi-member body at will, or at least for reasons other than not violating a statutory restriction. Indeed, even Myers $v$. United States, ${ }^{3}$ the zenith of presidential power, recognizes that there are certain functions that Congress may place in administrative agencies over which the President has no control, even where the agency heads are subject to his personal removal. Thus, while independence from discharge, except for cause, may be an additional ineans of protection from executive interference, it is by no means the only way that protection could be achieved, particularly with respect to adjudications.

It also has been suggested that multi-member bodies are needed in order to review decisions by administrative law judges, but that is not a rationale for independent agencies, only for inulti-inember agencies, most of which happen to be independent. Thus, administrative law judges at the Social Security Administration have their decision regularly reviewed not by independent agencies, but by the Appeals Council, which is a very different kind of entity. Moreover, once again, there is no necessary element in having a review of an administrative law decision by an independent commission: if you want multi-meniber review, you can provide for that with or without the factor of independence.

One of the interesting phenomena of the Reagan administration is that the independent regulatory agencies seem to be even less independent than they once were. Part of this may be due to the fact that President Reagan will serve two full terms, and thus any holdovers fron the prior administration will be long gone. In addition, the Reagan adnimis-

1. Paperwork Reduction Act of 1980, Pub. L. No. 96-511, 94 Stat. 2812.

2. 3 C.F.R. $\$ 127$ (1981), reprinted in 5 U.S.C. $\$ 601$ annot. at $431-34$ (1982).

3. 272 U.S. 52 (1926) (President has exclusive power of removal of executive officers appointed by and with advice and consent of Senate). 
tration has sought, and largely succeeded, in placing in all agencies, independent and otherwise, those who beheve firmly in the Reagan view of government-Deinocrats as well as Republicans. Therefore, the fact that the President cannot fire thein at will is of no significance, since most of these so-called independent commissioners would not dream of doing anything independent of what the President wanted anyway.

Take, for instance, Jaines Miller, who was initially in charge of the President's regulatory prograin at OMB, then became Chairman of the Federal Trade Commission, and then went back to OMB as its Direetor. His views were no inore (or less) independent in the middle job than they were in the other two, and hence whatever the theoretical claim of independence, the practical significance has been reduced considerably. Similarly, at the Admimistrative Conference ineetings, I have seen situations in which the Administration has taken a strong position on an issue and the views of representatives of independent agencies have not differed to any degree, either for or against the admimistration position, from those of purely executive branch meinbers.

There is another miportant control on independent agencies that brings thein closer to the administration position. Most independent agencies do not have their own hitigating authority, and thus when they go to court, they must ask the Department of Justice, which is nnder the direct control of the President, to represent thein. If the Justice Department refuses to go along, or insists upon taking positions different from those of the agency, there is nothing that can be done about it uuless the President can be inotivated to instruct the Attorney General otherwise, a highly unlikely situation. Even for those agencies, such as the National Labor Relations Board, which are permitted to hitigate inost of their own cases at the appeals court level, when it comes to Supreme Court litigation, including the all-iniportant decision whether to request review or not, that matter is cominitted to the exclusive province of the Solicitor General, who works directly for the Attoruey General and hence the President.

Having said that, I should note that in at least one case with which I am familiar, the Federal Energy Regulatory Commission took its unarching orders from Congress and fought in every way possible to prevent the constitutionality of the legislative veto in the Natural Gas Policy Act of 1978 from being decided on the inerits, when the Justice Department was doing its best to see that the issue was decided, and the veto was struck down. ${ }^{4}$ The court of appeals eventually rejected the views of the Com-

4. Consumer Energy Council of America v. FERC, 673 F.2d 425 (D.C. Cir. 1982), aff'd, 463 U.S. 1216 (1983). 
mission, and when the matter got to the Supreme Court, the Commission filed its papers, and the Justice Department filed its opposing views, but that is one of the rare times that occurred. Moreover, the Commission took no position on the constitutional issue, but simply argued the procedural grounds against the challengers.

An outsider looking at the presence of imdependent commissions might well ask, how is the decision made as to which commissions should be imdependent? Originally, most of the imdependent commissions were in the economic regulatory area, but that is not exclusively the case today. In some situations, the distinction between executive and independent agencies is plainly arbitrary, as evidenced by the fact that the Department of Transportation (DOT) regulates the safety of automobiles and the independent Consumer Product Safety Commission (CPSC) regulates the safety of lawnmowers, bicycles, and three- and four-wheel all-terrain vehicles. The decision to sphit the enforcennent function between those two bodies may or may not make sense, but it seems hard to justify the differences on needs for independence regarding the safety of Americans using those products. Indeed, insofar as I ain aware, the politics of the situation has affected regulation in both of those agencies to a nearly equal degree, although some would even argue that there has been more politics at the CPSC than at DOT.

Having said all this, does the conclusion necessarily follow that independent agencies can or should be abolished? One thing is clear, even raising that question is likely to cause a furor on Capitol Hill, for few ideas seem to offend members of the two Commerce committees more than suggesting that independents should be abolished. This reaction is plainly reflected in the decision of the President not to attempt to include imdependent agencies in Executive Order 12,9915 dealing with cost benefits and otlier regulatory matters, and it is surely a fact of political life that any such efforts would be met with substantial resistance.

On the other hand, there seems to be hittle mclination im Congress to take from the President the power to control the outcome of decisionmaking by pure executive agencies, even though when similar issues are presented to independent agencies, he lacks that power. Therefore, it seems to me, that given the mood of the Congress, there is likely to be hittle change in the landscape. Viewed analytically and compared with similar functions performed elsewhere, the independence of some agencies is plainly an anomaly, but tidmess in the government is not the only virtue.

5. 3 C.F.R. $\S 127$ (1981), reprinted in 5 U.S.C. $\S 601$ annot. at 431-34 (1982). 
While independent agencies may not be as independent as they once were, or as some people think they are today, there still remains a difference, and no one seems very much in favor of abohishing them. This balance brings to mind the remark of the pundit who said, "things are never as good or as bad as they seem," which im this context roughly translates into the proposition that the Securities and Exchange Commission, the Consumer Product Safety Commission, and the Federal Trade Commission are neither as dependent nor as independent as they sometimes seem, and the situation seems likely to continue that way for some time. 